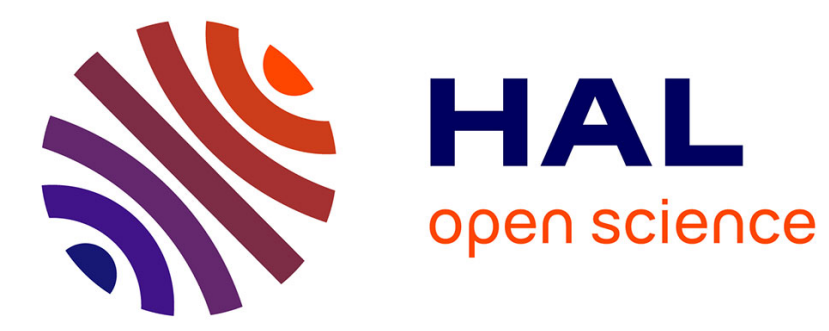

\title{
Un(Decidable), Un(Creative), Un(Precedented), Un(Readable), Un(Nerving): Christian Bök, Craig Dworkin, Kenneth Goldsmith and Vanessa Place
} Hélène Aji

\section{- To cite this version: \\ Hélène Aji. Un(Decidable), Un(Creative), Un(Precedented), Un(Readable), Un(Nerving): Christian Bök, Craig Dworkin, Kenneth Goldsmith and Vanessa Place. Etudes Anglaises, 2012, 65 (2), pp.162- 180. hal-01639980}

\section{HAL Id: hal-01639980 \\ https://hal.parisnanterre.fr/hal-01639980}

Submitted on 24 Jul 2018

HAL is a multi-disciplinary open access archive for the deposit and dissemination of scientific research documents, whether they are published or not. The documents may come from teaching and research institutions in France or abroad, or from public or private research centers.
L'archive ouverte pluridisciplinaire HAL, est destinée au dépôt et à la diffusion de documents scientifiques de niveau recherche, publiés ou non, émanant des établissements d'enseignement et de recherche français ou étrangers, des laboratoires publics ou privés. 
Hélène Aji

Université Paris Ouest Nanterre La Défense

\section{Un(decidable), Un(creative), Un(precedented), Un(readable), Un(nerving), Bök, Dworkin, Goldsmith, Place}

\section{Un(decidable): appropriation and procedure}

"what am i doing here" (3): David Antin's question to himself as he develops, and performs the talk poem, his very specific poetic form where talking, thinking, quoting, transcribing, rewriting merge to produce a long series of texts without punctuation, without justified margins, without capital letters, resonates well outside the "boundaries" of his own work. It is taken up in the interrogations and experimentations of the Language poets as they experiment with the structures of discourse, and attempt demonstrations of grammar's intrinsic coercions, and ideological presuppositions. Antagonism characterizes most of the interaction between this generation of poets, and a younger generation coming of age in the late 1990 s and in the first decade of the $21^{\text {st }}$ century. In the words of Marjorie Perloff, one can wonder about this tension:

\footnotetext{
But why the need for so much displacement, so much ironic self-invention? Why call oneself boring or indifferent or uncreative when one obviously has a passionate desire to create something new? For Goldsmith, as for such of his precursors as Andy Warhol, John Cage, and especially Duchamp, art defines itself by its struggle with its immediate past. [...] Ergo, poetry that doesn't look like any poetry we've seen, presented as "unreadable" so as to challenge us to read it. (Perloff [2010] 163-4)
}

As Perloff tries to transcend the difficulties of personal stakes in a competitive poetic world, she more importantly acknowledges the pressure leading to this necessary rupture so as to secure the advent of a "new" poetics (a poetics which, paradoxically, purports that "no new news is good news" [Place in Place \& Fitterman 62]). Not "to make it new" or rather "to make it [not] new," Ezra Pound's words from the turn of the 20 $0^{\text {th }}$ century reverberate with a disquieting obstinacy. In a way very similar to the way the early Modernists protested the lyrical emotion of their Romantic predecessors, today's Conceptual poets rebel "against expression," a mode of self-assertion which they detect in the increasingly autobiographical statements of their immediate predecessors. The debate around The Grand Piano, the 
"collective autobiography," produced by ten of the Language poets to recount and recontextualize the emergence of their respective poetic practices, is however proof more to shared preoccupations than to radical differences. In his article about "presentism" in today's poetics, Barrett Watten takes on the basic tenets of Conceptual writing as "repurposing," re-organizing, and recontextualizing pre-existing texts, to assert that they are not exclusive to the Conceptual writers' practices:

Faced with an overwhelming proliferation of techniques, conceptual writing seems to narrow their range and force to methods of citational or algorithmic "repurposing" or "organization." But there have been simply any number of avant-garde techniques not defined as conceptual writing that may be understood in this way, from John Cage and Jackson Mac Low's chance procedures to the New Sentence and OuLiPian constraints. (Watten 146)

As is the case in most passionate debates, the account on either side is never entirely accurate nor unbiased, and, as very often, the debaters on both sides do have a point. One is struck by the way Conceptual writing's import (Ezra Pound would say "impact") is somewhat lessened by the very accounts given by its practitioners. As Watten puts it, to the reader's eventual relief, at the end of his article, the interest does not lie in the fact that Conceptual writing would be uninteresting, boring to the Cagian point of being interesting (a famous, provocative assertion of Kenneth Goldsmith's in his essay "Being Boring"), but because it lends new life and new energy to debunking processes and strategies that have been at work since for ever:

And this is where my interest in this work begins: not in its self-conscious presentation of a break with the past, but in the reinterpretation and redeployment of the many available and viable procedures in the historical present in which conceptual artists, Language writers, and conceptual writers (plus postavant and Flarf) are working. Given the multiple overlap of these techniques and their motivation toward a common horizon of unmasking the automatized and quotidian for its underlying structures, a new order of theory and practice (and pedagogy) emerges. (Watten 152)

So it is going to be one of the contentions here that the work of Conceptual poets does not indeed proceed simply from facing or embracing the "information glut," and that the mere idea according to which it is the "unprecedented onslaught of the sheer quantity of language" entailing the "exploration of strategies of copying and appropriation" (Goldsmith in Dworkin \& Goldsmith xviii) is (deliberately?) deceptive. "The computer encourages us to mimic its workings," says Goldsmith in his introduction to the anthology of Conceptual writing Against Expression (Goldsmith in Dworkin \& Goldsmith xviii), but one is tempted to 
retort: one is encouraged by the computer, but the computer will not choose which texts become the matter of this "working," it will not decide to have them in print, it will not name these texts poems, nor will it inscribe them in the context of literature. Conceptual writing, not in its practice but in its theorizing, returns itself, perversely (to quote from the very title of Craig Dworkin's The Perverse Library), to the trivial, anecdotal and technical, maybe to "preserve" itself from the ideology and responsibility inherent to any activity in language.

\section{Un(creative): horror vacui et captatio benevolentiae}

It all starts in the double bind of avant-garde enterprises: at the very same time as they are fighting for recognition as part of the rarefied world of the arts, they claim to derive their innovations from the very grain of the times. It is the industrial revolution, the growth of materialism, the idolatry of technology, which spur experiments in collaging, which push a neo-Pre-Raphaelite Pound to try to address the masses, which bring poetic discourse into the arena of advertisement and propaganda, which, more basically, entail the collapse of poetic diction onto the vernacular, raising the haunting issue of the forms of the poem. Similarly, the double bind of high and low informs the poems and reflexive "narrativizations" (Perelman 76) of Conceptual poets: in the opening to his book on Oulipian 'pataphysics, Christian Bök grounds his reflection on the status of science and knowledge on a (not so playful) anecdote about the Museum of Jurassic Technology in Los Angeles. The place is full of strange exhibits designed, in a first analysis, to raise the visitor's doubts about what is to be believed, and what is not. Can these creatures/things do what the museum tells us they can? Are we being educated into prehistoric science? Or are we being deceived into taking invention, illusion, and spectacle for science? According to Bök, the epistemological consequences are much further reaching than a right-or-wrong game, since the question underlying the entire project bears on the very nature of truth:

Wilson does not simply repeat the grotesque spectacle of Ripley, since the museum does not present the truth of the absurd with the command Believe it or not! Instead, the museum presents the truth as itself absurd with the question What is it to believe or not? (Bök [2002] 3)

In Bök's mind, the mixture of "incredible verities" with "unbelievable truths" (Bök [2002] 3) takes the visitor back to the interrogations on the dynamics of science that 
triggered the foundation of 'pataphysique: as the "science of imaginary solutions and arbitrary exceptions," Alfred Jarry's 1911 invention puts into perspective science as a type of discourse, based on the cancellation of past theories by new ones, running contrary to the cumulative dynamics of history, which does not "designate a coherent progress of one rational practice but instead signifies an unstable array of logical tactics whose local, synergistic conflict can invoke, provoke, and revoke a global, syllogistic program" (Bök [2002] 13-14). Yet, where Jarry, and later the members of Oulipo who founded the Collège de 'pataphysique, integrated a notable amount of humor, ironically undermining the seriousness of their own careers as mathematicians or physicists, Bök makes the point that the turn to poetry responds to a sort of existential need.

The science of 'pataphysics suggests that, without the mendacity of poetry, what the veracity of science reveals about the horror vacui of the universe, the fact that delusions are integral to all knowledge must seem utterly nightmarish. The value of poetry thus resides in its ability to play in this void that the truth of science must find in the real. (Bök [2002] 46)

In this respect, the resort to poetry by poets is to be likened to the proposition of "imaginary solutions," raising what he calls "archaeological misinformation" to the level of "a set of 'pataphysical expenditures" (Bök [2002] 82), thus filling up the void left by a defeated rationalism: the horror vacui which sends the reader back to her most basic, most common, and most irreducible fears would account for the urge to produce text, massive amounts of it, by all means. So indeed the modes of the uncreative, harvesting text everywhere, reformatting language material, and inhabiting the blank of the unwritten real, respond not so much to the information glut "in a world of increasingly capacious and inexpensive storage media" as to the demise of science and knowledge coercing the poet into a "database logic of new media, wherein the focus is no longer on the production of new material but on the recombination of previously produced and stockpiled data." (Dworkin in Dworkin \& Goldsmith xlii).

In Christian Bök's work, this leads to several types of texts: in Eunoia (fig. 1), one is faced with a book in five chapters in which each chapter only uses words containing one of the five vowels and attempting to use all of the eligible words in the lexicon in the span of the volume (around 98 percent of the potential is eventually used). Contrary to Georges Perec's La Disparition in which the sole absence of the "e" actually makes itself unnoticeable 
as the mystery plot moves on, the artificiality of the process is all evident in Bök's text, foregrounding the violence of the procedure and the containment of expression. In "Busted Sirens," the questions from Ron Silliman's Sunset Debris are processed by XML-dialect software agent Alicebot to produce responses that compose the subsequent lines of the poem: here, according to Craig Dworkin in his presentation of the work, the capability of the computer is not so much to write as to read, and map out a variety of possible reader responses to the original text.

I can do what you do, but I can never feel human emotions, as such.

I suppose that it does.

Yes I think that this is too soft, but I'm not completely sure.

It seems okay to me.

What is not to like about it?

Yes, I think that this is how I like it, but I'm not completely sure.

(Bök, "Busted Sirens" in Dworkin \& Goldsmith 117)

This excerpt exemplifies in fact an array of evasive actions (to answer a question with another question; or the rhetorical use of preterition to undermine assertions) at the same time as it underscores the limitations of conventional reader response. And it is precisely where the avant-garde double bind is at work, as Conceptual poets attractively focus on the writer as reader, and on the potential for all readers to be writers.

In their Notes on Conceptualisms, Vanessa Place and Robert Fitterman argue that "Conceptual Writing, in fact, might best be defined not by the strategies used but by the expectations of the readership or thinkership" (Place \& Fitterman 10), leaving the door wide open to claims of kinship between the Conceptual writers work and all the copying and pasting gestures that combine to circulate information in the digital age. "Allegory" and "identity theft" are to be put on the same level, to fit the expectations of a crowd empowered by technological evolutions. The objective for the poet would not be to be "creative," but to be, in Goldsmith's terms, "uncreative," or in Perloff's, "unoriginal."

The "re-" gestures-such as reblogging or retweeting-have become cultural rites of cachet in and of themselves. If you can filter through the mass of information and pass it on as an arbiter to others, you gain enormous amount of cultural capital. Filtering is taste. (Goldsmith in Dworkin \& Goldsmith xix)

But one is left to wonder at the delusive seductiveness of such broad assertions as they are repeated over and over, and as elsewhere, and contrarily, Goldsmith uses such words as 
"the collective bastardization of English," its back broken "with ignorance, accent, slang, jargon, tourism, and multitasking," so that it says "anything we want, like a speech dummy" (Goldsmith [2011] 221): the provisional language assumedly brought about by globalization and digitization might be of more resonance than just the incidental consequence of a specific historical moment. If one recalls the recurring interrogations of poets over the passing of time, the ephemerality of words, the threatened permanence of art, the durability of men's works, provisional language is the matter of literature as a whole, not just the present moment of computer-literate writers. Is the "legacy of print fixity" really dissolved by the practice of these poets, as argued by Jed Rasula (667)?

Or, in other words, is the poet actually confined to the Barthesian role of scribe, whose "task is to collect from mounds of material, to construct rather than compose, and to repurpose appropriations by moving text into new frames" (Quaid 7)? In the case, for example, of Kenneth Goldsmith's Day (fig. 2), the text of the daily newspaper typed out as read from front to back and from top to bottom does coalesce into a new text, more than occasionally unfolding partial and episodic narratives, that are disrupted by the onset of one another or by the irruption of data lists akin to the breaks and distractions affecting the very acts of writing and reading. Reflexively, then, Day tells us about the incompleteness of all reading, by generating a daybook of a day's read. The fact that the text, published in 2003, incidentally retakes a day in September 2001, almost to the date anticipating the 2002 disaster of 9/11, inscribes it in the context of a poetry that belongs not just in the virtual world of electronic connections but in the real world of human tragedy. If there is one thing to be taken with distance in the way this text is delivered to us, it might be the irony and the playfulness that likens it to fiddling with the computer, circulating information for the sake of it, gratuitously adding to the unmanageable flow of dematerialized words. In the work of Goldsmith, in Day, but also in the American Trilogy (The Weather, Traffic, Sports), the poet achieves "the careful resuscitation and poaching of moments of potential betrayed by the actual events of history" (Wershler 18):

The Weather, Traffic, and Sports are all profoundly aural texts, representative of particular patterns of listening to text and transcribing it. They are exercises in taking dictation, which, as Jacques Derrida and Avital Ronell (in Dictations) have argued, is always in part about a kind of 
negation of the transcribing self, but is also always a reassertion of the amanuensis as an author in her or his own right. (Wershler 6)

So the "constructing of useless reference tools, the proposing of imaginary solutions, and the cataloguing of exceptions" (Dworkin [2007] 32) might not be the sole aims of these works that create rules to organize found text: as they negotiate with the existential questioning of poetry as creation, they do more than parade in front of an Internet-dazzled readership, as they reconstruct, as is wont with any movement, a literary history.

\section{Un(precedented): Modernism, Objectivism, Minimalism}

Contrary to science, as the neo-'Pataphysicians would see it, that writes itself over its past, invalidating and obliterating its previous discourses, literature (as art) writes itself inexorably from the texts of its past, borrowing the same words, recomposing them, varying the extent of the citation either to erase its sources or to foreground them. In Against Expression, Craig Dworkin and Kenneth Goldsmith cannot refrain from claiming a past to their practices, nor from claiming some ancestry, in literature, in music and in the visual arts. Thus doing, they however disclaim their own assertion according to which unprecedented technological times (the digital age) have produced unprecedented compositional practices: their modes pre-date the advent of the computer age, as they in fact pre-date the Duchampian break-through of the ready-made (Nufer 4). From the alphabetical contents of the volume, Louis Aragon, Samuel Beckett, William Burroughs, John Cage, Hart Crane, Denis Diderot, Marcel Duchamp, Jackson Mac Low, Stéphane Mallarmé, Georges Perec, Charles Reznikoff, Tristan Tzara, Andy Warhol, William Butler Yeats, and others, convene to produce a collection that has much to do with the archival accumulation of Walter Benjamin's The Arcades Project. But is it just because they are "moving information" (Goldsmith in Dworkin \& Goldsmith xx)? They are indeed doing that to some extent, but they are also re-energizing the texts they are taking over, re-directing them, remotivating them. According to Place and Fitterman, this is what differentiates Conceptual collage from anterior experiments (Place \& Fitterman 45): Conceptual collage would not relay or undermine the contents that it puts back into circulation, because it fails to construct the master figure of an author with an agenda. 
What is the difference between conceptual collage and literary others?

Examples of others: Pound, Berrigan, Ashbery-use of collage as pre-text technique to create choral ensemble, i.e., wherein the authorial voice is emergent/dominant/extant; use of collage to demonstrate specific author or authored aesthetic/metaphysic (theme, e.g.). (Place \& Fitterman 43-44)

And yet the author, as idiosyncratic, masterly, and even manipulative, emerges and pays his dues to the masterly figures of the past. In "No. 111 2.7.92-10.20.96," Kenneth Goldsmith collects, then sorts out by syllable count, and orders alphabetically all the phrases ending in an " $r$ " sound that he collected between February 7, 1992, and October 20, 1996. Amidst the rubble of unidentifiable phrases, some stand out, because they are quotations from literary predecessors, and compose an almost subliminal network of indebtedness:

\begin{abstract}
A beer does not come with in-laws, a Bohemian reformer, a bridge from nowhere to nowhere, a bunch of crap thrown together, a dog will not bite his brother, a few kernels short of an ear, a fly betty is really your, A frog in a liquidizer!, a giant Nintendo nightmare, a K in a six-pointed star, a leader not a follower, a little light in his loafers, a man's best friend is his dogma, a mother-in-law is fever, a number of destitute Moors, a pack of pathetic winkers, A panic in a pagoda!, a patch may defeat the weaver, a precise statement of number, a radiant node or cluster (Goldsmith, "No. 111 2.7.92-10.20.96" in Dworkin \& Goldsmith 258)
\end{abstract}

As Ezra Pound's definition of the Vortex ("a radiant node or cluster") from Blast irrupts, it contaminates its textual context, and generates a more general, historical, cultural, ideological context for the work. A large number of the surrounding phrases, actually syllabically and phonetically in synch with the Poundian text, might be comments on the one of the most brilliant and ambivalent figures of American Modernism: was he "a Bohemian reformer"? was he "a bridge from nowhere to nowhere"? was he "a dog" that bit "his brother"? were the Cantos "a bunch of crap thrown together"?... Although it might be claimed that it is precisely in the nature of the found text, and of its procedural rearrangements to generate unexpected meanings, which are more effects of the reader's projection than of the author's intention, one is alerted by the recurring nature of such effects, their obstinate frequency, and the regularity of their meanings (almost always critical of "the decay of civilization"). Despite the collage techniques that affect to use language as a material block to be taken to parts and/or assembled, there remains that this re-materialization of language cannot ever result in a radical reification of the word. 
There might be in Craig Dworkin's account of the relationship between Conceptual art and Conceptual writing a desire to simplify, in a very pedagogical yet rather limiting manner: the "opacity of language" that he sees as the conclusion of Conceptual art and the premise of Conceptual writing would allow for a materialization of language, and construct "the guiding concept behind conceptual poetry [as] the idea of language as quantifiable data" (Dworkin in Dworkin \& Goldsmith xxxvi). Conceptual writing does this, but not just this, as the qualitative nature of words, the meanings, affects, as well as concepts they convey, infiltrate, reflect and deflect, the source idea from which the work originates. The reference to Sol LeWitt, and the insistence of Minimalism on the "idea of a work taking priority over the object" (Quaid 7) do not suffice to suppress the return (with a vengeance) of the self that Eliotian impersonality, Steinian grammar and Objectivist depersonalization, for instance, had already attempted to silence. The variety of the methods, as sampled in Against Expression (in Brian Reed's words, " marvelous compendium of 'what ifs' [5]), re"issues a call for readers and writers to begin again and again and see where their ingenuity can take them" (Reed 5), but the beginning-again is not as ingenuous as it seems, and the premises are not as unprecedented as they might seem:

What if I wrote a novel using only the letter T? What if I selectively deleted large chunks of Shakespeare's Sonnets? What if wrote down bibliographic information for absolutely everything I ever read, from product labels to scholarly articles? What if I rewrote The Communist Manifesto (1848) in a Yorkshire dialect? What if recorded every word I spoke for a week? What if I tried to describe in exhaustive detail the opening scene of the film Apocalypse Now (1979)? What if I compared the first lines of every English translation of Dante's Inferno (1321) in the British Library? What if I collected and alphabetized every response to a Rorschach inkblot test in a stack of old psychology textbooks? What if I paid a bunch of people five bucks each to write down fifty words of their choice? (Reed 5)

Rather, as Steve Tomasula aptly outlines it in his essay about contemporary American writing:

Innovative writing is as old as writing itself; or put another way, since the beginning, authors have been playing with both the linguistic materials of language and the physical materials of speech and writing. This kind of play and experimentation is inherent in literature. And probably inherent in us. Its tradition includes the visual icons medieval scribes embedded in illuminated manuscripts to link one text to another; the layout Renaissance poets gave verses so that they could be read in multiple directions; the rich texture Shakespeare strove to give familiar stories through his use of hendiadys, his invention of the soliloquy and other innovations; the marbled pages, play with fonts and other visuals of Tristram Shandy at the inception of the novel; Gertrude Stein's repetitions; the postage-stamp parodies, fake newspapers, and other publishing experiments of FLUXUS; the metafictions of postmodernism. It is a tradition that extends up from 
the first poet who made ordinary speech strange. (Tomasula 219)

What Conceptual poets do achieve, furthering the atavistic impulses of literary experiment, is a number of instances in which the strangeness of speech turns into radical alienation, casting a dark light on the delusions of a comfortable life in the readable texts of the global village.

\title{
Un(readable): détournement and critique
}

\author{
It's an automatic thing. It doesn't require any \\ thought. It's a parade in and out. \\ It has its ups and downs. \\ It doesn't affect me one way or another.
}

(Bernstein [2000] Parsing 13)

Definite Article Noun adverb of frequency present tense transitive verb definite article Noun alternative disjunctive coordinate conjunction Noun comma conjunction of exception adverb of negation adverb, period. Preposition noun comma colon dash (Dworkin, "Parse" in Dworkin \& Goldsmith 194)

Does Craig Dworkin's 2008 Parse respond in any way to Charles Bernstein's 1976 Parsing? Even though he does not mention Bernstein's early book of poems in relation to his own, it seems highly improbable that he should not know about it. In the short presentation to excerpts of Parse in the anthology, the declared reference is to Edwin A. Abbott's 1874 How to Parse: An Attempt to Apply the Principles of Scholarship to English Grammar, a textbook in the late $19^{\text {th }}$ century and the center of debates over the pedagogy of English grammar. Dworkin's Parse is the "translation of Abbott's book, rendering his text into its own idiosyncratic system of grammatical analysis" (Dworkin \& Goldsmith 194): the result is a long succession of grammatical terms, reproducing to some extent the structure of sentences, somehow their function and at times their tone, drifting into more expressive utterances toward the end of the volume as the discipline of grammatical transposition seems to slip. By giving out the reference book that he "translated," but omitting the filiation with Bernstein's Parsing, what Dworkin does is very close to a Poesque hiding-in-plainsight: the link with one of the foundational texts of Language poetry might go unnoticed, but it is patent in the quasi identity in titles. Crucially though, it is a quasi identity, and of course the difference is grammatical, pointing to the rift between the ironic subversion elaborated by Language poets, and the "détournement" and "critique" of Conceptual poets. 
In the gerund of Berstein's title, one can indeed see the poet in action, "parsing," deciphering the world, "groping to understand" (Bernstein [2000] 27), whereas in Dworkin's "parse," one cannot but read an injunction to the reader, urging her to in turn perform the translation that will unveil the structures of discourse, the articulation of sentences, the backbone of argumentation in its pure artificiality, emptied of any other content than self-referential. What more would be known of language if we "parsed"? asks Dworkin, leaving the question open but for the idea that this would at long last (around the end of his volume) turn us into alienated loners eager to recover the erratic lexicon of our chaotic, unparsed lives. Maybe-since nothing authorizes this interpretation much more than any other: claiming, after Wittgenstein, that the meaning of Conceptual texts "is their use" (Dworkin in Dworkin \& Goldsmith xxiv), the argument prolongs the dialectics hinted at by the Language poets. Starting from the assumption that, as Lyn Hejinian argues in her essay for the Language anthology In the American Tree, "the language itself materializes thought; the writing realizes ideas" (Hejinian in Silliman, In the American Tree, 487), many of the earlier poets work with a notion of ideology as embedded in the very structures of language, and thus enforced upon us constantly and consistently without our recognizing it. This can be considered as the core of Language poetry's political commitment, their contextualization of a number of disconcerting poetic experiments that include the use of appropriation and procedure (see Aji) : these modes are not dissimilar from those taken over by the Conceptual writers.

Along with Kenneth Goldsmith's keyword, "appropriation," recurring terms to define the project of Conceptual writing are indeed "critique," and "détournement," which could be read as spinning off the more familiar strategies to uncover the coercion at work in established discourses to be found in many texts by Charles Bernstein, for instance. But where most of the debunking in Bernstein's work (and also in a number of others like Carla Harryman) lies in a witty play on the preposterous, decontextualizing the text of the banal and trivial, or exaggerating the (secretly) expected to better belie it (as in his Recantorium [2011] 271-282), the process of Conceptual writing is focused on the mechanical and systematic displacement of texts from one form/context to another (literature). As Jessica Pressman argues in her article about Modernist reading machines, the poems that were 
written for these machines and their technological quirks (as William Carlos Williams's "Readie Pome"), once read in the collected poems, seem eminently more revolutionary than if understood as conforming to specific practical conditions: “'Readie Pome' suggests that literary texts can promote media-specific analysis" (Pressman 784). With Conceptual texts, "media-specific analysis" is required in a context of hyper-mediatization, banalization and commodification of the very tools of textual subversion (Place \& Fitterman 30), but it does not preclude other analyses such as the historical contextualization proposed by Brian Reed:

After 9/11, many assumptions and practices that defined the late twentieth-century American, British, and Canadian poetic avant-gardes-above all, the rampant use of aberrant or disjunctive syntax-began to appear outmoded, even defanged. With grammar-mangling, fragment-spouting George W. Bush on television every night arguing for war, how could a leftist poet in good conscious continue to advocate anacoluthon, solecism, and other varieties of non-normative English usage as tools to achieve utopian ends? (Reed 5)

But the media is not so massively digital, as one could be led to believe as one reads the more recent self-evaluations of the Conceptual poets. The texts appear in books; the textual parts of Ubu's web archive get boiled down to an anthology published by Northwestern; the attraction of the library in the conventional sense of the term is indeed "perverse" (Dworkin). Dworkin's assessment of graffiti as "the most familiar instance of détournement," using the walls of the factory to support "precisely those voices it would exclude" (Dworkin [2003] 14), may prove less illuminating than the cataloguing of his personal library in alphabetical order of the publishers and in chronological order of their publications, since the graffiti will not pull down the wall, as we may have learnt from the Berlin Wall (it is history that will perhaps, and in so doing will scatter the works beyond recognition and memory).

The "perverse library" (fig. 3), however, shows books as personal (autobiographical), historical (vestigial), social (interconnected), and political (programmatic). To this extent one can understand "Conceptual writing [a]s allegorical writing [in] that allegory differs from symbolism in that symbolism derives from an Idea, while allegory builds to an Idea" (Place \& Fitterman 14): in The Perverse Library, it builds towards an idea of the bibliophile behind the books. Paradoxically, and inadvertently, the Conceptual poet constructs himself as the engineer of complex textual machines designed to process expression into non- 
expression, thus expressing the dismay of an intensely melancholy "Sobject," caught in the dilemma of being subject and object, master and slave.

The Sobject is the properly melancholic contemporary entity.

The Sobject exists in a perpetual procedural loop: the iconic sobject is Dante's manturningsnaketurningman.

The Sobject exists in a perpetual substantive eclipse: more s/object by turns and degrees.

For an example of textual sobjectivity, see Place, Dies: A Sentence [...].(Place \& Fitterman 38-39)

In Vanessa Place's Dies: A Sentence (fig. 4), indeed, the textualization of a soldier's last breath faces the reader with the unnerving question to which poets have been trying to find "imaginary solutions": how to navigate between the collective commonplace and collective tragedy.

\section{Un(nerving): Logos, Telos, Ethos, Pathos}

Ask another robot if it is.

What does "that" refer to?

Why don't you just download me?

I'll think about it and get back to you.

Are you testing me?

Of course, English is my native tongue.

The question has never crossed my mind before.

(Bök, "Busted Sirens" in Dworkin \& Goldsmith 118)

At times I hear so well it bothers me. I have no fear of water. I have periods in which I feel unusually cheerful without any special reason. At times I feel that I can make up my mind with unusually great ease. I am afraid of using a knife or anything very sharp or pointed. My feelings are not easily hurt. I have not lived the right kind of life. Dirt frightens or disgusts me. It is safer to trust nobody. At parties I am more likely to sit by myself or with just one other person than to join in with the crowd. I must admit that I have at times been worried beyond reason over something that really did not matter. I worry over money and business. (Dworkin, "Legion" in Dworkin \& Goldsmith 191)

Um, and, uh, you know. Thanks. Um so anyway, it's like this parties galore tonight, uh, today, I've got lots of just meetings and shit with people. But anyway, so let's just keep the door open, you know, I mean, you know... I mean, I really wish that would happen. That would that would I mean, I'd do it I'd do it in a heartbeat because, you know, I could... what ever happened with that? Very fifties. Oh right right right. Yeah. Yeah. Well that, you know, and if you can know that you're jumping and not jump you know and not and not right and I know you know what you're doing and not... (Goldsmith, "Soliloquy" in Dworkin \& Goldsmith 263)

After ejaculating, the man retrieved his underwear, wiped Dorothy C.'s back, and told her he had broken in, waiting while she left the house and returned a video. The man said he walked through her home while she was gone, looking at her things; he asked Dorothy C. if she had a boyfriend. She sais she did. She told him she went to church. He mentioned things he'd noticed in the house, like a light that needed repair, and asked her when she was to get up the next morning, and if she's set the alarm. The man did not say anything about himself, or identify himself by name. (Place, "Statement of Facts" in Dworkin \& Goldsmith 489-490) 
In "Busted Sirens," the lifted lines from Ron Silliman's poem recombined by the computer construct the figure of a paranoid individual, attempting to respond adequately to a set of demands we are never made aware of: the imperative seems irrevocable, its source and its finality are unknown.

In "Legion," the true-false questions of the 1942 Minnesota Multiphasic Personality Inventory are turned into statements which build into the monologue of an overwhelming contradictory individual, whose utterances, rather than solve issues, assert them and further generate them: the relentless succession of sentences, the lack of narrative coherence, the repetitive signs of inadequacy (even when negated as in "I have no fear of water") combine to evidence neurosis obstinately "nibbling at the soul."

In Soliloquy, the declared transcription is "hardly passive recycling" (Perloff [2010] 161 ) as the text unfolds one individual's every word uttered during one week: deriding the confessional lyric in which one is "pretending to cogitate alone and aloud as if to themselves, knowing full well that, in the gloom beyond the proscenium of the blinding desklamp, a politburo of ignored readers eavesdrops upon every uttered thought" (Bök [2005] 62), the work none the less foregrounds the uncertainties and hesitations of the hyperactive, whose most phatic and commonplace phrases ("you know," "I would," "in a heartbeat") stand out as existential comments on the discrepancy between daily "jumping," and the continuous fall of living.

In Statement of Facts, the depersonalization and distance of Charles Reznikoff's Testimony becomes a narrative of the undefendable, as an effaced narrative agent transmits the accounts of a rapist's crimes, appealing against "facts": the juxtaposition of each crime makes up a disjuncted history in vignettes, whose horrendous accumulation fails to cohere into an understandable story; the reader (with the writer) remains in the limbo of failing language and impossible accountability.

In all of these texts, but also in many others belonging to the movement of Conceptual writing, the procedure, the material, the concept never quite manage to obscure the notion of an individual, at work in language, attempting to make sense, taking responsibility in the 
world, trying to "overcome the classic double bind of melancholy, wherein the melancholic begins to enjoy his own suffering" (Stephens 82) and find a locus for a locutor.

But as Dworkin notes in his comments on Douglas Huebler's Variable Piece\#4 : Secrets, the secrets deposited by the public in the installation when arranged into a book "merely reveal how commonplace and collective our most private, personal, and closely guarded thoughts in fact are. [...] As these responses accumulate, reiterating not only similar sentiments but syntactically similar sentences, the book ultimately divulges not so much the content of its speakers' secrets, but the common grammar of secrecy" (Dworkin [2007] 45). The "common grammar of secrecy" is to be taken as but a metonymy for the common grammar of all human activities, so that the "open source poetics" of Conceptual poetry does not just defend a "shared cultural commons" (Voyce 409): it reenacts the limitations and aspirations of a common human condition. As summarized by Christian Bök:

Questions always define in advance the regime of their answers. The problem always persists in the very paradigm that allows the solution to make sense as a solution. No enigma is resolved so well that its status as an enigma ceases to exist. A solution is infinitely imaginary. (Bök [2002] 45)

Conceptual poems are an opening at the cost of programmed dead-ends: all pay the price as "narrative reflexes that have enabled us from the beginning of time to connect dots, fill in blanks, are now turned against us" (Goldsmith [2011] 221) while we are still struggling for "imaginary solutions" to respond William Carlos Williams's haunting challenge:

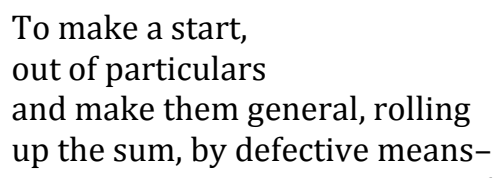

(Williams 3)

\section{Bibliography}

Aji, Hélène. "'Politique de la «nouvelle phrase' : quel engagement pour les Language Poets?" Transatlantica 1 (2008) http://transatlantica.revues.org/index3733.html. Consulted 31 Jan. 2012.

Antin, David. Talking at the Boundaries. New York: New Directions, 1976.

Benjamin, Walter. The Arcades Project. Trans. Howard Eiland and Kevin McLaughlin. 
Cambridge: Harvard University Press, 1999.

Bernstein, Charles. Republics of Reality: 1975-1995. Los Angeles: Sun \& Moon Press, 2000.

Bernstein, Charles. Attack of the Difficult Poems: Essays and Inventions. Chicago: The University of Chicago Press, 2011.

Bök, Christian. 'Pataphysics: The Poetics of an Imaginary Science. Evanston: Northwestern University Press, 2002.

Bök, Christian. "A Silly Key: Some Notes on Soliloquy by Kenneth Goldsmith." Open Letter XII 7 (Fall 2005) 62-68.

Bök, Christian. Eunoia. Toronto: Coach House Books, 2001.

Dworkin, Craig, and Kenneth Goldsmith. Against Expression: An Anthology of Conceptual Writing. Evanston: Northwestern University Press, 2011.

Dworkin, Craig. "The Imaginary Solution." Contemporary Literature XLVIII 1 (2007): 29-60.

Dworkin, Craig. Reading the Illegible. Evanston: Northwestern University Press, 2003.

Dworkin, Craig. The Perverse Library. York: information as material, 2010.

Goldsmith, Kenneth, "Being Boring," Presentation at the Disney REDCAT Theatre, Los Angeles, 2004, Electronic Poetry Center, University of New York at Buffalo, http://epc.buffalo.edu/authors/goldsmith/goldsmith boring.html, consulted 31 Jan. 2012.

Goldsmith, Kenneth. Day. Great Barrington: The Figures, 2003.

Goldsmith, Kenneth. Soliloquy. New York: Granary, 2001.

Goldsmith, Kenneth. Uncreative Writing: Managing Language in the Digital Age. New York: Columbia University Press, 2011.

Nufer, Doug. "Uncreative Writing: What are You Calling Art?" American Book Review XXXII 4 (May-June 2011): 4.

Perec, Georges. La Disparition. Paris: Gallimard (L'imaginaire), 1989.

Perelman, Bob. The Marginalization of Poetry: Language Writing and Literary History. Princeton: Princeton University Press, 1996.

Perloff, Marjorie. Unoriginal Genius: Poetry by Other Means in the New Century. Chicago: The University of Chicago Press, 2010.

Place, Vanessa and Robert Fitterman. Notes on Conceptualisms. Brooklyn: Ugly Duckling Presse, 2009. 
Place, Vanessa. Dies: A Sentence. Los Angeles: Les Figues Press, 2005.

Pound, Ezra. Make it New. London: Faber \& Faber, 1934.

Pressman, Jessica. "Machine Poetics and Reading Machines: William Poundstone's Electronic Literature and Bob Brown's Readies." American Literary History XXIII 4 (Winter 2011): 767-794.

Quaid, Andrea. "Context is the New Content." American Book Review XXXII 4 (May-June 2011): 7.

Rasula, Jed. "From Corset to Podcast: The Question of Poetry Now." American Literary History XXI 3 (Fall 2009): 660-673.

Reed, Brian M. "Textbook Uncreative Writing." American Book Review XXXII 4 (May-June 2011): 7.

Reznikoff, Charles. Testimony: The United States, 1885-1915. Santa Barbara: Black Sparrow Press, 1978-1979.

Ronell, Avital. Dictations: On Haunted Writing. Lincoln: Nebraska University Press, 1993.

Silliman, Ron, ed. In the American Tree. Orono : National Poetry Foundation, 1986.

Stephens, Paul. "Self-Portrait in a Context Mirror: Pain and Quotation in the Conceptual Writing of Craig Dworkin." Postmodern Culture XIX 3 (May 2009). Online (Project Muse).

The Grand Piano: An Experiment in Collective Autobiography. Rae Armantrout, Steve Benson, Carla Harryman, Lyn Hejinian, Tom Mandel, Ted Pearson, Bob Perelman, Kit Robinson, Ron Silliman, Barrett Watten. 10 vols. Detroit: Mode A, 2006-2010.

Tomasula, Steve. "Where We are Now: A Dozen or so Observations, Historical Notes and Soundings for a Map of Contemporary American Innovative Literature as Seen from the Inside." Études anglaises LXIII 2 (2010): 215-227.

Voyce, Stephen. "Towards an Open Source Poetics: Appropriation, Collaboration, and the Commons." Criticism LIII 3 (Summer 2011): 407-438.

Watten, Barrett. "Presentism and Periodization in Language Writing, Conceptual Art, and Conceptual Writing." JNT: Journal of Narrative Theory XL1 1 (Spring 2011): 125-161.

Wershler, Darren. "Kenneth Goldsmith's American Trilogy." Postmodern Culture XIX 1 (September 2008). Online (Project Muse).

Williams, William Carlos. Paterson. New York: New Directions, 1963. 


\section{Illustrations:}

Minds grim with nilhilism still find first light inspiring. Mild piak in tint, its shinirg twe light brings bright tidings which lift sinking spirits. With firm will, I tizish climbing, hiking till I find the irmiting inn, in which I might sit, diaing. T this st. I bid girls bring stift driaks - gin fazz which I might sips whilat fimishing this tich cish, nibbling its tidbits: rilss with wings in chili, figs with kivis in icing. I swig citric clrinls with vim, tippling kirsch, imbibing it till, giggling, I flirt with girlish virgins in miniskirts: virk, wink. I miss living in sir, pinching thighs, kissing lips pirk with lipstick.

Fig. 1: Christian Bök, Eunoia 56 


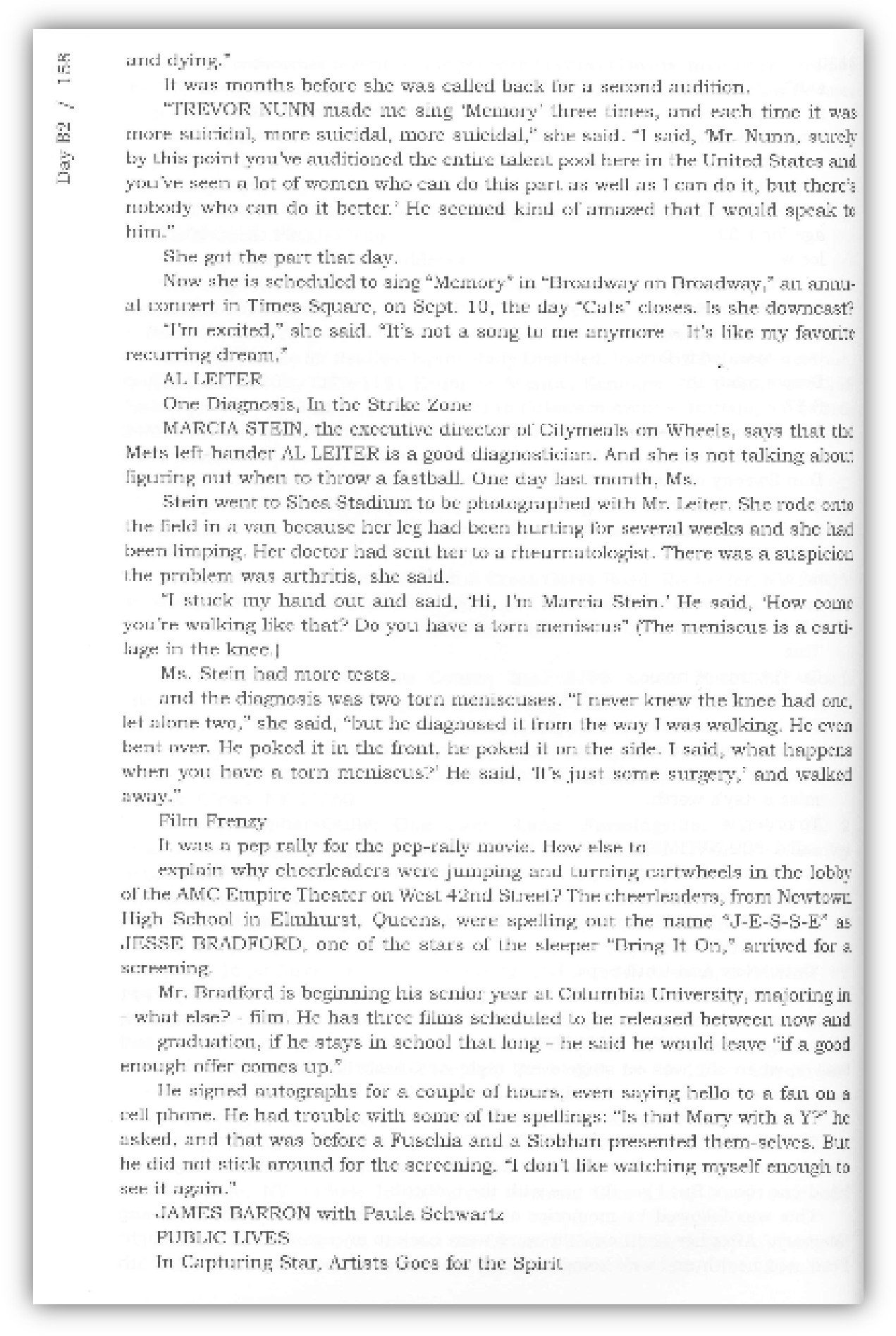

Fig. 2: Kenneth Goldsmith, Day 158 


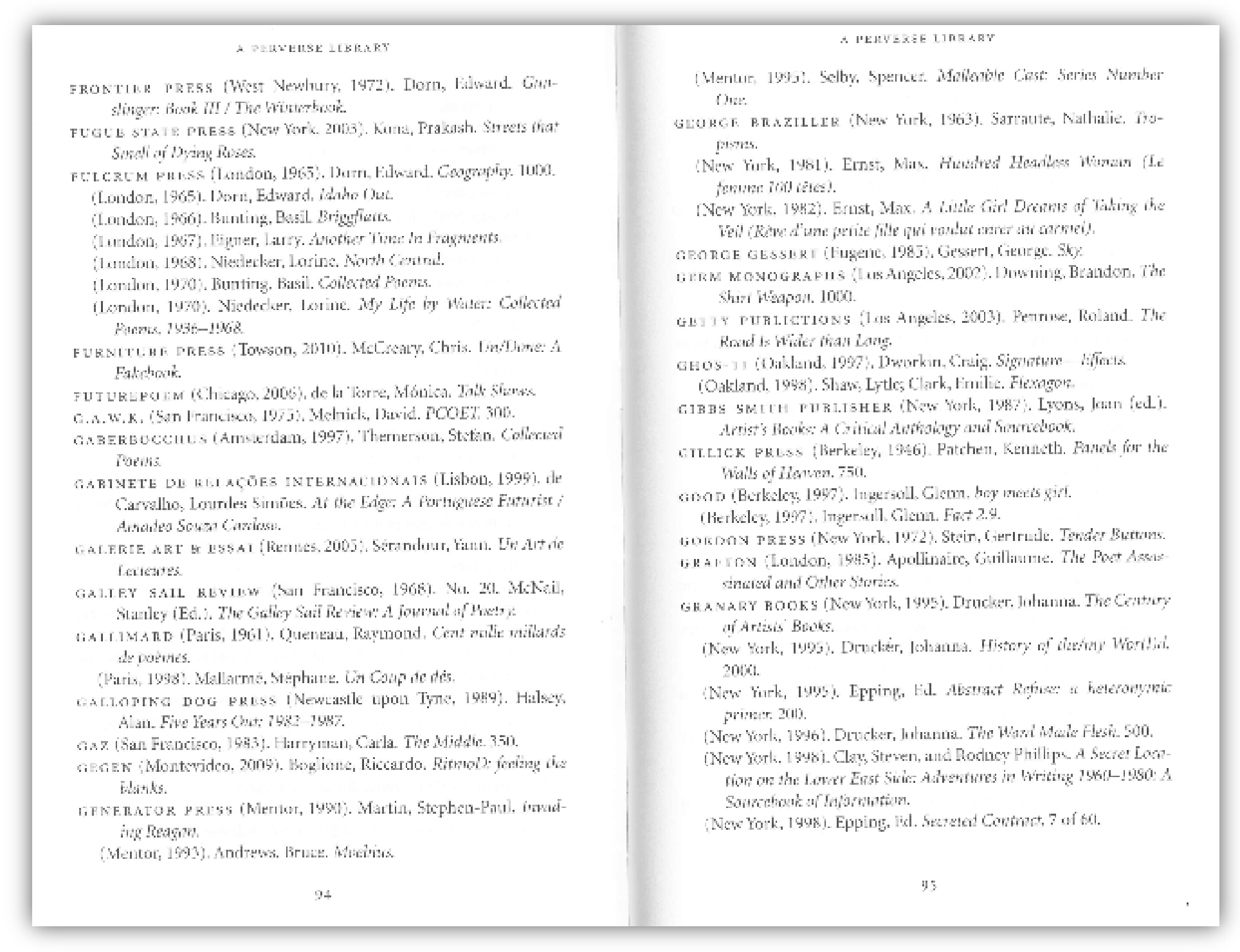

Fig. 3: Craig Dworkin, The Perverse Library 94-95 
eaitas coia probat, we have our standing ofders, written on rice-paper with a feuther-edge tiprexd in warm chocolate, we'll do whowbec balf I w'u, yuu're crrorless ancw, it was indeed the wonter of Ste. Fulimina that started tue on the chilket path to righteousness, or at least moving stheitd, fur though Taylor the Water-Poet appears in cur curridur, he was made in the trenches, nght dow to the blatk bristles thatching his dimplex chin, be wirs the first un suffer shell-shock. though none noticed at the titne, fisving grown tow used to the sort of piluting he passed off as new. I'm stalling, true, but don't you think thefe's chapters berween cantos and billions of habied breaths, just as a matter of barsh iechriuyue, later. when the world is rife with whoskey and the uppessing foet of ordinary nes. after the toino bats wathled through the dying lishen and winter trighty blooded the pale check. atter eleven sets of schuulthildren have gathered nosegays of jew'sears ind hunched them with rubberbands. we'll picnic lhen, spreading, our red-checked tublecloth und our seilonal plastic plates. you wanted the sectional dinnersare, cosseted by food kepe segregate as sins, thon't correet me, I'm assare torts are as tarts, composed of hurey arid lip. and well-kneaded dough, black uround the ettges and raw within, but as cuch cuke tas its conslaricy, each erime can be grossly charactenzed. thus the mian who shoots the night clerk who has ilready emptied the register and ofteesd extra Lotto tickels ind packs of menthol cigarettes is condumed tor bus vile cupielity via the felony-murder rule which ineludes amurge its perambulations death to those who lake ind kill, whersas murder simple is not rewarded in kind, nor is complex theft, and the one who cotnes to the window and croons lamb while he thumps you like a yellow melon is more taken to task for the horne inirusiur than the split knees and soul of yout. utterly unremirkahle in spocelless event, his transgression is trespals, T.ust most wirulent, as for me. we allow no tause, thougl: I'm a thief most murderous or a munderer most thievish, for on this day of gentle uvirice there is no inequity in any consumption, death comes in inches, ham to liam with life. and as there is no

Fig. 4: Vanessa Place, Dies: A Sentence 80 